Dept. of Food Hygiene,

Animal Health Research Institute, Assiut Branch, Assiut.

\title{
INCIDENCE AND CHARACTERIZATION OF E. COLI O157:H7 ISOLATED FROM MINCED BEEF, CHICKEN MEATS AND HUMAN STOOLS IN ASSIUT CITY
}

(With 3 Tables and 2 Figures)

By

SOHAILA FATHI HASSAN ALI; R. HASSANEIN*; A. MOHAMED ABD EL-MALEK and K. IBRAHIM ELSAYH**

* Dept. of Animal Hygiene and Zoonoses, Faculty of Veterinary Medicine, Assiut University, Assiut. ** Dept. of Pediatric, Faculty of Medicine; Assiut University, Assiut 71526, Egypt (Received at 1/3/2010)

مدى تواجد وتوصيف الإيشيريشيا كولاى 0157:H7 المعزولة من اللحوم المفرومة، لحوم الاواجن وبراز الإنسان في مدينة أسيوط الإئئ

سهيلة فتحي حسن على ، رأفت حسنبن ، أشرف محمد عبد المالك خاللد إبراهيم السايح

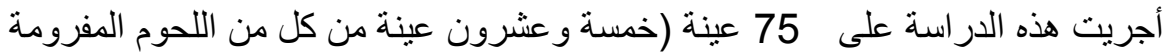

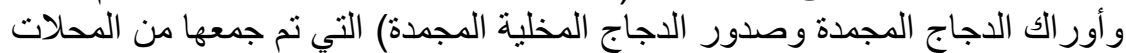

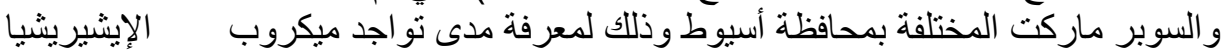

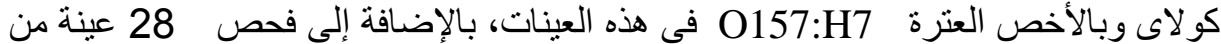

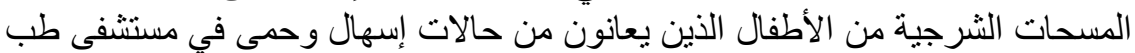



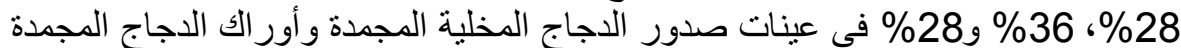

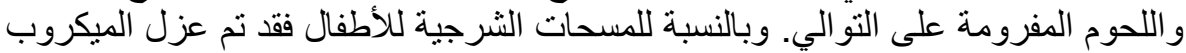

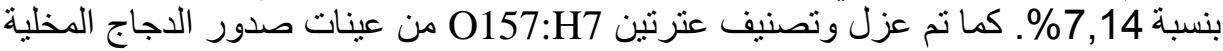

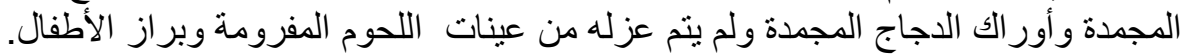

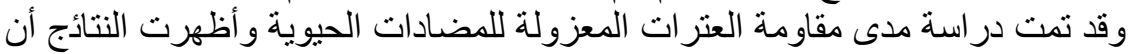

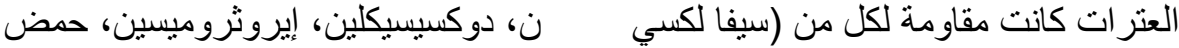

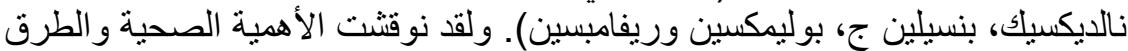
الو اجب إتباعها للحد من تلوث منتجات اللحوم و الدو اجن بهذا الميكروب. 


\section{SUMMARY}

Meat and meat products have been implicated in outbreaks of Escherichia coli $\mathrm{O} 157: \mathrm{H7}$ in most parts of the world. A total of 75 samples including 25 samples each of frozen chicken breast fillets, frozen chicken legs and minced frozen beef were randomly collected from retail supermarkets in Assiut, Egypt. In addition, 28 stool cultures collected from hospitalized children admitted in Assiut Pediatric University Hospital with history of diarrhea or fever. All were screened for the presence of E. coli especially E. coli O157:H7. E. coli was detected in 7 (28\%), $9(36 \%), 7(28 \%)$ and $2(7.14 \%)$ of chicken frozen fillet, chicken frozen leg, minced frozen beef and children stool samples, respectively. Two strains of $E$. coli $\mathrm{O} 157: \mathrm{H} 7$ were isolated one from each of chicken frozen fillet and chicken frozen leg samples, while it could not be detected in any of minced frozen beef or children stool samples. The two isolated strains were tested for antibiotic resistance. They were found to be resistant to seven antimicrobial agents (cephalexin, doxycycline, erythromycin, nalidixic acid, penicillin G, polymyxin B and rifampicin). The public health significance of this pathogen and consumer's safety were discussed.

Key words: Escherichia coli- E. coli $\mathrm{O} 157: \mathrm{H} 7$, minced beef, chicken fillet, chicken legs, children stools.

\section{INTRODUCTION}

The microbiological safety of meat products is an important public health concern. Numerous epidemiological reports have identified pathogenic Escherichia coli, particularly E. coli O157:H7, as major cause of disease outbreaks associated with contaminated meat (Olsvik et al., 1991; Meng and Doyle, 1998).

E. coli $\mathrm{O} 157: \mathrm{H} 7$ was first recognized as a human enteric pathogen in 1982 when it caused two major outbreaks of hemorrhagic colitis in the USA (Riley et al., 1983). From that time, it has been responsible for hundreds of cases and outbreaks throughout the temperate regions of the world and is considered to be one of the most important and potentially life-threatening pathogens. E. coli O157:H7 has the ability to cause hemorrhagic colitis, hemolytic uremic syndrome (HUS), thrombotic thrombocytopenic purpura and, in severe cases, death (Tarr, 1995). 
E. coli $\mathrm{O} 157: \mathrm{H} 7$ has emerged as an important food-borne pathogen of considerable public health concern, because of the severity of infection which it causes and an infectious dose which may be as low as 10 organisms (Coia, 1998). In an outbreak study reported by Willshaw et al. (1994) contamination levels in an implicated product were reportedly as low as 2 cells per $25 \mathrm{~g}$. This pathogen has been implicated in a number of high-profile outbreaks in the USA (Bell et al., 1994), Scotland (Ahmed and Donaghy, 1998) and Japan (Michino et al., 1998) as well as in many sporadic cases of infection.

E. coli is a normal part of the intestinal micro-flora of many healthy animals, and in humans. However, some strains can cause diseases. Minced beef has been contaminated with E. coli $\mathrm{O} 157: \mathrm{H} 7$ as a result of contamination the meat during slaughtering. The intestinal tract or hides are considered the main sources of such contamination (Karch et al., 2005).

One of the major problems that accompany E. coli $\mathrm{O} 157: \mathrm{H} 7$ infection is the danger of treating such patients with antibiotics (Wong et al., 2000; Okoli et al., 2005). Wong et al. (2000) warn that treating E. coli $\mathrm{O} 157: \mathrm{H} 7$ infections may result in the release of shigatoxins into the blood stream of the infected individuals. It is believed that the release of such toxins affects the kidneys resulting in a condition described as HUS and it presents a great challenge in the treatment approach to be adopted in the case of E. coli $\mathrm{O} 157: \mathrm{H} 7$ infections.

In a view of the importance of $E$. coli $\mathrm{O} 157: \mathrm{H} 7$ from a food safety standpoint, this study was planned to investigate the presence of this food pathogen in some selected meat, poultry products and children stool as well as the antibiogram profiles of the E. coli $\mathrm{O} 157: \mathrm{H} 7$ isolates.

\section{MATERIALS and METHODS}

\section{Collection of Samples:}

A total number of 75 samples of meat and chicken products (25 samples each of minced frozen beef, frozen chicken legs and frozen raw skinless chicken breast fillets) were used in the study. The meat and chicken products were purchased from different retail supermarkets and groceries in Assiut city. All of the samples were transferred directly to the laboratory in an ice box for bacteriological examination.

\section{Preparation of samples:}

At the laboratory, frozen samples were thawed by overnight refrigeration. Each sample was aseptically and carefully freed from its casings and mixed thoroughly in sterile mortar. 


\section{Children samples:}

To identify the occurrence of $E$. coli $\mathrm{O} 157: \mathrm{H} 7$ infections in hospitalized children in Assiut, cases study were conducted. Theses cases admitted in Pediatric Univ. hospital; Assiut Univ., with diarrhea or fever. A stool culture examined for E. coli $\mathrm{O} 157: \mathrm{H} 7$ and the parents of the cases were interviewed, using a standardized questionnaire including addressing the family's consumption of, purchasing and preparation conditions for various foods such as poultry and beef, and their contacts with people having diarrhea.

Isolation of $\boldsymbol{E}$. coli 0157:H7 (De Boor and Heuvelink, 2000): Selective enrichment:

For enrichment, Ten grams of each meat and chicken product samples as well as swabs from children stools were aseptically added to 90 milliliters of modified Tryptic Soya Broth (m TSB) supplemented with $20 \mathrm{mg} / \mathrm{L}$ Novobiocin (Sigma, Germany). The meat and chicken samples were stomached $(230 \mathrm{rpm})$ for $2 \mathrm{~min}$. and incubated at $37^{\circ} \mathrm{C}$ for $24 \mathrm{~h}$.

\section{Selective plating:}

Loopful from the incubated broth was streaked onto the surface of sorbitol MacConkey agar (SMAC) (Oxoid, CM813) plates and incubated at $37^{\circ} \mathrm{C}$ for $24 \mathrm{~h}$. Non sorbitol fermenter colonies were picked up and streaked onto Eosin Methylene Blue agar (EMB) (Oxoid, CM69) and incubated at $37^{\circ} \mathrm{C}$ for $24 \mathrm{~h}$. for further identification.

\section{Identification of isolates:}

Metallic green colored, smooth sided colonies on EMB were identified morphologically by Gram's stain and biochemically confirmed as E. coli according to Varnam and Evans (1991) by the conventional IMViC, Urea hydrolysis, Triple sugar iron agar and fermentation of sugars (lactose, sucrose and sorbitol).

Serological identification of $\boldsymbol{E}$. coli 0157:H7 (Chan et al., 2005):

The biochemically identified non sorbitol fermenting colonies from SMAC were subjected to slide agglutination with the E. coli $\mathrm{O} 157$ latex test kit (Oxoid, DR620 M) and the agglutinating colonies were further processed for definite confirmation.

Identification of $\mathbf{H 7}$ (Johnson, 2004):

A single typical well isolated colony was cultured on Hichrome EC O157:H7 agar plates (HiMedia, M1574) and incubated at $37^{\circ} \mathrm{C}$ for $24 \mathrm{~h}$. Hichrome EC O157:H7 agar contains sorbitol and a proprietary chromogenic mixture instead of lactose and indicator dyes respectively. The chromogenic substrate was specifically and selectively cleaved by 
E. coli $\mathrm{O} 157: \mathrm{H} 7$ resulting in dark purple to magenta colored moiety. Other E. coli gave light pink colored colonies.

\section{Antibiotic susceptibility test:}

The isolated E. coli $\mathrm{O} 157: \mathrm{H} 7$ strains were tested for antibiotic resistance to ten antimicrobial agents obtained from Bioanalyse [amikacin $(30 \mu \mathrm{g})$, cephalexin $(30 \mu \mathrm{g})$, ciprofloxacin $(5 \mu \mathrm{g})$, doxycycline $(30 \mu \mathrm{g})$, erythromycin $(15 \mu \mathrm{g})$, gentamicin $(10 \mu \mathrm{g})$, nalidixic acid $(30 \mu \mathrm{g})$, penicillin $\mathrm{G}$ (10 units), polymyxin B (300 units) and rifampicin $(30 \mu \mathrm{g})]$ using the disc diffusion method according to the criteria of the National Committee for Clinical Laboratory Standards (NCCLS, 2000). The isolates were classified as sensitive, intermediate and resistant using the breakpoints of the NCCLS (2000).

\section{RESULTS}

The obtained results are recorded in Tables 1-3 and Fig. 1\&2

Table 1: Isolation rate of Escherichia coli from different food and children samples.

\begin{tabular}{|c|c|c|c|}
\hline \multirow{2}{*}{ Type of samples } & $\begin{array}{c}\text { No. of examined } \\
\text { samples }\end{array}$ & \multicolumn{2}{|c|}{ Positive samples } \\
\cline { 3 - 4 } & 25 & 7 & $\%$ \\
\hline $\begin{array}{c}\text { Chicken frozen } \\
\text { fillets }\end{array}$ & 25 & 9 & 36 \\
\hline $\begin{array}{c}\text { Chicken frozen } \\
\text { legs }\end{array}$ & 25 & 7 & 28 \\
\hline $\begin{array}{c}\text { Minced frozen } \\
\text { meats }\end{array}$ & 28 & 2 & 7.14 \\
\hline Children stools & 103 & 25 & 24.27 \\
\hline Total & & & \\
\hline
\end{tabular}

Table 2: Incidence of $E$. coli $\mathrm{O} 157: \mathrm{H} 7$ in meat, chicken products and children stools.

\begin{tabular}{|c|c|c|c|}
\hline \multirow{2}{*}{ Type of samples } & \multirow{2}{*}{$\begin{array}{c}\text { No. of examined } \\
\text { samples }\end{array}$} & \multicolumn{2}{|c|}{ Positive samples } \\
\cline { 3 - 4 } & & No. & $\%$ \\
\hline Chicken frozen fillets & 25 & 1 & 4 \\
\hline Chicken frozen legs & 25 & 1 & 4 \\
\hline Minced frozen meats & 25 & - & - \\
\hline Children stools & 28 & - & - \\
\hline Total & 103 & 2 & 1.94 \\
\hline
\end{tabular}


Table 3: Antimicrobial susceptibility of two E. coli O157:H7 strains isolated from poultry product samples.

\begin{tabular}{|l|c|c|c|c|}
\hline $\begin{array}{c}\text { Antibiotic } \\
\text { agent }\end{array}$ & $\begin{array}{c}\text { Antibiotic } \\
\text { disc content }\end{array}$ & $\begin{array}{c}\text { Sensitive } \\
\text { No.(\%) }\end{array}$ & $\begin{array}{c}\text { Intermediate } \\
\text { No.(\%) }\end{array}$ & $\begin{array}{c}\text { Resistant } \\
\text { No.(\%) }\end{array}$ \\
\hline Amikacin & $30 \mu \mathrm{g}$ & $2(100)$ & - & - \\
\hline Cephalexin & $30 \mu \mathrm{g}$ & - & - & $2(100)$ \\
\hline Ciprofloxacin & $5 \mu \mathrm{g}$ & $2(100)$ & - & - \\
\hline Doxycycline & $30 \mu \mathrm{g}$ & $1(50)$ & - & $1(50)$ \\
\hline Erythromycin & $15 \mu \mathrm{g}$ & - & - & $2(100)$ \\
\hline Gentamicin & $10 \mu \mathrm{g}$ & $2(100)$ & - & - \\
\hline Nalidixic acid & $30 \mu \mathrm{g}$ & $1(50)$ & - & $1(50)$ \\
\hline Penicillin G & $10 \mathrm{U}$ & - & - & $2(100)$ \\
\hline Polymyxin B & $300 \mathrm{U}$ & $1(50)$ & - & $1(50)$ \\
\hline Rifampicin & $30 \mu \mathrm{g}$ & - & $1(50)$ & $1(50)$ \\
\hline
\end{tabular}

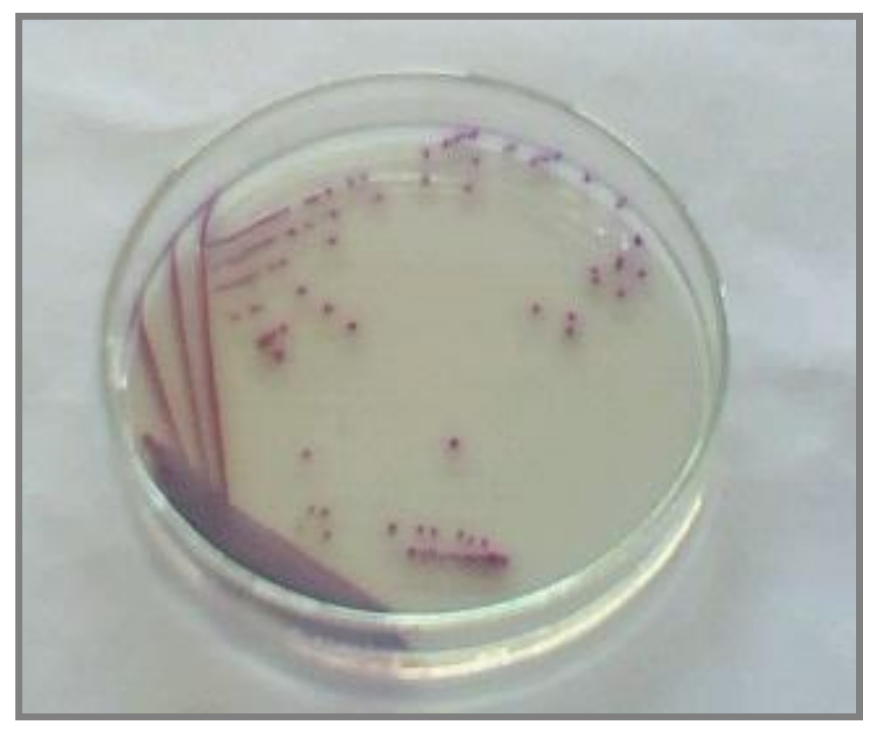

Fig. 1: E. coli 0157:H7 colonies on the Hichrome EC 0157:H7 agar. E. coli 0157:H7 give dark purple to magenta coloured colonies. 


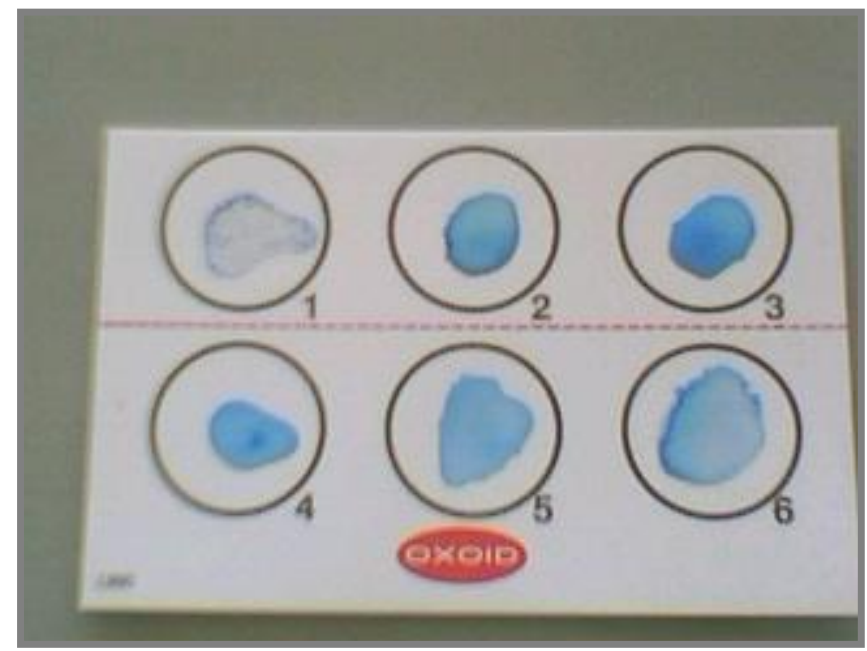

Fig. 2: E. coli O157 latex test

Samples No.1

Samples No.2

Samples No. 3 \& 4

Samples No.5\&6 control positive.

control negative. negative samples. positive samples.

\section{DISCUSSION}

Because the reservoir of $E$. coli is the intestinal tract of both man and animals, the presence of such organism in foods and water is used as indicator of faecal pollution either directly or indirectly (ICMSF, 1978).

A total of 75 meat and poultry product samples as well as 28 children stool samples were analyzed and determined the levels of $E$. coli in the examined samples. According to the data in Table (1), Twenty five $E$. coli strains were isolated, resulting in an overall prevalence of $24.27 \%$. Positive isolates of E. coli were observed in 16 out of 50 poultry samples, followed by 7 of 25 minced meat samples and 2 of 28 children stool samples. Among the examined samples poultry products were the most frequently contaminated with E. coli (32\%), compared with minced meat (28\%) and children stools $(7.14 \%)$. (Zhao et al., 2001) has demonstrated that the incidence of E. coli in retail meats was $38.7 \%$ in chicken and $19 \%$ in beef. Regarding minced meat, similar results $(25.2 \%)$ was obtained by Zhao et al., 2002 in U. S. While higher levels were obtained by Vorster et al. (1994). They showed that $74.5 \%$ of ground beef and $79.15 \%$ of broilers bought in the Pretoria area were 
contaminated with E. coli. Interestingly, more recent investigations revealed much higher rates in beef (69\%) and chicken (68\%) (Kegode et al., 2008).

The differences in contamination levels could be affected by the national or geographic characteristics of meat sources, processing environments, and different methodologies such as numbers, amounts and periods of samples tested (Kegode et al., 2008).

In recent years, scientists have identified a rare but dangerous type of Escherichia coli, E. coli $\mathrm{O} 157: \mathrm{H} 7$ that is responsible for serious bacterial gastroenteritis food-borne illness (Wong et al., 2000).

Beef minced meat samples have been examined in several countries for the presence of E. coli O157:H7: in Netherlands, 1.1\% of 571 samples of raw minced beef was contaminated (Heuvelink et al., 1999), in India, Dutta et al. (2000) isolated E. coli O157:H7 from two (9\%) out of 22 minced beef samples. In Turkey, Baran and Gulmez (2005) isolated E. coli $\mathrm{O} 157: \mathrm{H} 7$ from three (6\%) of ground beef samples. Positive isolation of E. coli $\mathrm{O} 157: \mathrm{H} 7$ from beef samples in Egypt was reported by Tanios et al. (2002) from two (6.7\%) of minced meat samples and Abd El-Aziz (2004) who isolated the organism in a rate of $6 \%$.

Although minced meat have been widely implicated as a vehicles of E. coli $\mathrm{O} 157: \mathrm{H} 7$ infection, we have not isolated the organism from minced meat samples in the present study. Similar results were reported by Noveir et al. (2000); Fantellli and Stephan, (2001); Uhitil et al., (2001) and Dontorou et al. (2003).

Results of serological identification of sorbitol negative E. coli isolates revealed that $E$. coli $\mathrm{O} 157: \mathrm{H} 7$ was detected in one sample (4\%) of each chicken frozen fillet and chicken frozen leg samples (Table 2). These findings corroborate those of Abdul-Raouf et al. (1996) who isolated the organism from 2 of $50(4 \%)$ chicken samples. Doyle and Schoeni (1987) isolated E. coli O157:H7 from 4 (1.5\%) of 263 poultry samples and stated that the organism is not a rare contaminant of poultry meats. On the other hand, Baran and Gulmez (2005) failed to isolate E. coli $\mathrm{O} 157: \mathrm{H} 7$ from chicken drumstick samples.

The isolation of E. coli $\mathrm{O} 157: \mathrm{H} 7$ from foods is problematic because the bacterium is likely to be present in low numbers, may be sublethally injured, and is usually accompanied by large populations of competing microflora, including other E. coli.

Symptoms of E. coli O157 infection include bloody and nonbloody diarrhea, vomiting and abdominal cramps. Illness resolves 
typically within 7-10 days. A subset of patients, particularly the young and the elderly, will develop HUS, characterized by microangiopathic hemolytic anemia, thrombocytopenia, and renal failure (Russell et al., 2000). In the United States, HUS is the principal cause of acute kidney failure in children, and E. coli $\mathrm{O} 157: \mathrm{H} 7$ causes most cases of HUS (Besser et al., 1999). An estimated 73,480 people a year are infected with E. coli $\mathrm{O} 157: \mathrm{H} 7$ and about 600 of those cases are fatal, according to the Federal centers for Disease Control and Prevention (Wong et al., 2000). These illnesses and deaths were factors that began changing policy towards food-borne disease.

E. coli $\mathrm{O} 157: \mathrm{H} 7$ failed to be isolated from children stool samples because our cases suffering from fever and diarrhrea but non of our cases showed symptoms suggestive of HUS.

Recent studies have revealed a trend towards increased antibiotic resistance of E. coli O157:H7 (Amornrut et al., 2000; Magwira et al., 2005). For instance, in 2005 about 35\% of E. coli O157:H7 strains isolated from meat and meat products in Gaborone, Botswana, were resistant to cephalothin, sulfatriad, colistin sulfate and tetracycline (Magwira et al., 2005).

In the present study, E. coli $\mathrm{O} 157: \mathrm{H} 7$ isolates were resistant to 7 out of 10 antibiotics namely: cephalexin, doxycycline, erythromycin, nalidixic acid, penicillin $\mathrm{G}$, polymyxin $\mathrm{B}$ and rifampicin. However, some isolates were either intermediately susceptible (I) and /or fully susceptible (S) to some antibiotics (Table 3).

Antibiotic resistance may occur either spontaneously by selective pressure or because of antibiotic miss-use by humans or over-use by farmers (Schroeder et al., 2002). Although antibiotic resistance is common, antibiotics are still indicated in the management of life threatening disease like diarrhea. However, the use of antibiotics in the management of $E$. coli $\mathrm{O} 157: \mathrm{H} 7$ infection in humans is still controversial due to the possible development of HUS (Wong et al., 2000).

The contamination risk of raw meat products with E. coli O157:H7 and other pathogens constitute a major problem for human. Consequently, it must be kept in mind that Good Manufacturing Practices (GMP) and the implementation of a Hazard Analysis Critical Control Point (HACCP) system in food manufacturing and preparation can help to control this organism (Attenborough and Matthews, 2000). In addition, effective heat treatment for foods, provision of information to food handlers and consumers as well as application of strict hygienic 
measures during manufacturing, storage and selling of these products improve its quality and safeguard the consumers against infections with such organism.

\section{REFERENCES}

Abd El-Aziz, Doaa, M. (2004): Microbiological and chemical hazards of some meat products. M. V. Sc. Thesis. Fac. Vet. Medicine, Assiut University, Assiut, Egypt.

Abdul-Raouf, U.M.; Ammar, M.S. and Beuchat, L.R. (1996): Isolation of Escherichia coli O157:H7 from some Egyptian foods. Int. J. Food Microbiol., 29: 423-426.

Ahmed, S. and Donaghy, S. (1998): An outbreak of Escherichia coli O157:H7 in Central Scotland. In: Kaper, J.P. and O'Brien, A. D. (Eds), Escherichia coli O157:H7 and other Shiga Toxinproducing E. coli strains, ASM Press, Washington DC: 59-65.

Amornrut, L.; Manthana, P.; Boonchuay, E.; Sathaporn, M.; Samruay, T.; Sontana, S.; Kenichi, N.; Tetsuya, I.; Chaisit, N. and Podjanee, K. (2000): Shiga toxin and enterotoxin-producing Escherichia coli isolated from subjects with bloody and nonbloody diarrhea in Bangkok, Thailand. Diag. Microbiol. Infect. Dis., 46: 173-180.

Attenborough, A. and Matthews, K.K. (2000): Food safety through the meat supply chain. J. Appl. Microbiol., 88: 144-148.

Baran, F. and Gulmez, M. (2005): Escherichia coli O157:H7 in the ground beef and chicken drumsticks. Internet J. Food Safety, 2: 13-15.

Bell, B.P.; Goldoft, M.; Griffin, P.M.; Davis, M.A.; Gordon, D.C. and Tarr, P.I., et al. (1994): A multistate outbreak of Escherichia coli O157:H7-associated bloody diarrhea and haemolytic uraemic syndrome from hamburgers. The Washington experience. J. Am. Vet. Med. Assoc., 272: 1349-1353.

Besser, R.E.; Griffin, P.M. and Slutsker, L. (1999): Escherichia coli O157:H7 gastroenteritis and the hemolytic uremic syndrome: an emerging infectious disease. Annu. Rev. Med., 50: 355-367.

Chan, E.; Ball, L. and Horsman, G.B. (2005): Comparison of four latex for detection of E. coli O157. Clin. Lab. Sci., 11(5): 266-268.

Coia, J.E. (1998): Clinical, microbiological and epidemiological aspects of Escherichia coli $\mathrm{O} 157$ infection. FEMS Immunol. Med. Microbiol., 20: 1-9. 
De Boor, E. and Heuvelink, A.E. (2000): Methods for the detection and isolation of shiga-toxin producing E. coli. J. Appl. Microbiol. Symposium supplement. 88: 133-143.

Dontorou, C.; papadopoulou, C.; Filioussis, G.; Economou, V.; Apostolou, I.; Zakkas, G.; Salamoura, A.; Kansouzidou, A. and Levidiotous, S. (2003): Isolation of Escherichia coli O157:H7 from foods in Greece. Int. J. Food Microbiol., 82: 273-279.

Doyle, M.P. and Schoeni, J.L. (1987): Isolation of Escherichia coli O157:H7 from retail fresh meats and poultry. Appl. Environ. Microbiol., 53: 2394-2396.

Dutta, S.; Deb, A.; Chattopadhyay, U.K. and Tsukamoto, T. (2000): Isolation of Shiga toxin-producing Escherichia coli including O157:H7 strains from dairy cattle and beef samples marketed in Calcutta, India. J. Med. Microbiol., 49: 765-767.

Fantelli, K. and Stephan, R. (2001): Prevalence and characteristics of shigatoxin-producing Escherichia coli and Listeria monocytogenes strains isolated from minced meat in Switzerland. Int. J. Food Microbiol., 70 (1-2): 63-69.

Heuvelink, A.E.; Zwartkruis-Nahuis, J.T.; Beumer, B.R. and de Boer, E. (1999): Occurrence and survival of verocytotoxin-producing Escherichia coli $\mathrm{O} 157$ in meat obtained from retail outlets in the Netherlands. J. Food Prot., 62: 1115-1122.

International Commission on Microbiological Specification for Foods (ICSMF) (1978): Microorganisms in foods, their significance and methods of enumeration. $2^{\text {nd }}$ ed. Uni. Of Toronto Press, Toronto.

Johnson, R. (2004): Pre-harvest detection and control of verotoxin (shiga toxin)-producing Escherichia coli. $23^{\text {rd }}$ World Buiatrics Congress, Quebec, Canada, July 11-16, 2004.

Karch, H.; Tarr, P. and Bielaszewska, M. (2005): "Enterohaemorrhagic Escherichia coli in human medicine." Int. J. Med. Microbiol., 295 (6-7): 405-418.

Kegode, R.B.; Doetkott, D.K.; Khaitsa, M.L. and Wesley, I.V. (2008): Occurrence of Campylobacter species, Salmonella species and generic Escherichia coli in meat products from retail outlets in the Fargo metropolitan area. J. Food Safety, 28: 111-125.

Magwira, C.A.; Gashe, B.A. and Collison, E.K. (2005): Prevalence and antibiotic resistance profiles of Escherichia coli $\mathrm{O} 157: \mathrm{H7}$ in beef products from retail outlets in Gaborone, Botswana. J. Food Prot., 68: 403-406. 
Meng, J. and Doyle, M.P. (1998): Emerging and evolving microbial food-borne pathogens. Bulletin de L'Institut Pasteur, 96: 151-164.

Michino, H.; Araki, K.; Minami, S.; Nakayama, T.; Ejima, Y.; Hiroe, K.; Tanaka, H.; Fujita, N.; Usami, S.; Yonekawa, M.; Sadomoto, K.; Takaya, S. and Sakai, N. (1998): Recent outbreaks of infections caused by Escherichia coli $\mathrm{O} 157: \mathrm{H} 7$ and other shiga toxin-producing E. coli strains. ASM Press, Washington D.C.: 73-81.

National Committee for Clinical Laboratory Standards (NCCLS) (2000): Performance standards for antimicrobial disk susceptibility tests. In: Approved Standards M2- A7, seventh ed. National Committee for Clinical Laboratory Standards, Wayne, PA.

Noveir, M.R.; Dogan, H.B. and Halkman, A.K. (2000): A note on Escherichia coli O157:H7 serotype in Turkish meat products. Meat Sci., 56: 331-335.

Okoli, C.I.; Chah, K.F.; Ozoh, P.T.E. and Udedibie, A.B.I. (2005): Antimicrobial resistance profile of $E$. coli isolates from tropical free range chickens. J. Health Apllied Sci., 3: 1-12.

Olsvik, O.; Wasteson, Y.; Lund, A. and Hornes, E. (1991): Pathogenic Escherichia coli found in food. Int. J.Food Microbiol., 12: 103-113.

Riley, L.W.; Remis, R.S.; Helgerson, D.S.; McGee, H.B.; Wells, J.G.; Davis, B.R.; Herbert, R.J.; Olcott, E.S.; Johnson, L.M.; Hargett, N.T.; Blake, P.A. and Cohen, M.L. (1983): Hemorrhagic colitis associated with a rare Escherichia coli serotype. N. Engl. J. Med., 308: 681-685.

Russell, J.B.; Diez-Gonzalez, F. and Jarvist, G.N. (2000): Effects of diet shifts on Escherichia coli in cattle. J. Dairy Sci., 83: 863-872.

Schroeder, C.M.; Zhao, C.; Debroy, C.; Torcolini, J.; Zhao, S.; White, D.G.; Wagner, D.D.; McDermott, P.F.; Walker, R.D. and Meng. J. (2002): Antimicrobial resistance of Escherichia coli O157 isolated from humans, cattle, swine and food. Appl. Environ. Microbiol., 68: 576-581.

Tarr, P.I. (1995): Escherichia coli O157:H7: Clinical, diagnostic and epidemiological aspects of human infection. Clin. Infect. Dis., 20: $1-10$. 
Tanios, A.I.; Shaaban, A.I.; Abd EL-Atty, I. and EL- Shernoby, R. (2002): Serological features of pathogenic E. coli in meat and meat products. J. Egypt. Vet. Med. Assoc., 62 (3): 245-253.

Uhitil, S.; Jakšić, S.; Petrak, T. and Botka-Petrak, K. (2001): presence of Escherichia coli O157:H7 in ground beef and ground baby beef meat. J. Food Prot., 64: 862-864.

Varnam, A.H. and Evans, M.G. (1991): Food borne pathogens. An illustrated Textbook. Wolfe Publishing Ltd., New York: 209-234.

Vorster, S.M.; Greebe, R.P. and Nortjé, G.L. (1994): Incidence of Staphylococcus aureus and Escherichia coli in ground beef, broilers and processed meats in Pretoria, South Africa. J. Food Prot., 57: 305-310.

Willshaw, G.A.; Thirwell, J.; Jones, A.P.; Parry, S.; Salmon, R.L. and Hickey, M. (1994): Verocytotoxin producing E. coli 0157 in beefburgers linked to an outbreak of diarrhea, haemorrhagic colitis and haemolytic uraemic syndrome. Lett. Appl. Microbiol., 19: 304-307.

Wong, S.C.; Jelacic, S.; Habeeb, R.L.; Watkins, S.L. and Tarr, P.I. (2000): The risk of the hemolytic uremic syndrome after antibiotic treatment of Escherichia coli O157:H7 infections. N. Engl. J. Med., 5: 23-28.

Zhao, C.; Ge, B.; De Villena, J.; Sudler, R.; Yeh, E.; Zhao, S.; White, D.G.; Wagner, D. and Meng, J. (2001): Prevalence of Campylobacter spp., Escherichia coli and Salmonella serovars in retail chicken, turkey, pork and beef from the greater Washington, D.C., area. Appl. Environ. Microbiol., 67: 5431- 5436.

Zhao, T.; Doyle, M.P.; Fedorka-Cray, P.J.; Zhao, P. and Ladely, S. (2002): Occurrence of Salmonella enterica serotype Typhimurium DT 104A in retail ground beef. J. Food Prot., 65: 403-407. 